\title{
SUNFLOWER (Helianthus annuus L.) RESEARCHES IN THE AEGEAN REGION OF TURKEY
}

\author{
Tan, A.S. \\ Ministry of Agriculture and Rural Affairs, General Directorate of Agricultural \\ Research, Aegean Agricultural Research Institute, Plant Genetic Resources \\ Department, PO Box: 9, Menemen, 35661 Izmir, Turkey
}

Received: April 10, 2010 Accepted: August 10, 2010

\section{SUMMARY}

Sunflower (Helianthus annuus L.) is one of the important oilseed crops with a high oil percentage (45-50\%) and oil quality. It can be grown in both the first and second crop production seasons in the Aegean Region with high yield capacity.

According to the production data of 2008, sunflower was produced on 577,958 ha and 992,000 metric tons of sunflower seed were harvested in Turkey (Anonymous, 2010). Because of the gap in vegetable oil production in Turkey, sunflower is one of the alternative and leading oilseed crops for increasing vegetable oil production. One possibility for increasing this production is for sunflower to also be grown as the second crop in the Aegean Region.

The mission of the Oilseed Research Project at the Aegean Agricultural Research Institute (AARI) is to reduce the cost of sunflower production by improving well adapted and high yielding varieties. A number of different approaches are utilized to achieve this goal. Improved germplasm for hybrid development and breeding lines of oilseed and confectionary type of sunflower germplasm (A, B and $R f$ lines) and also improved populations have been developed by conventional breeding techniques. To improve sunflower varieties with desired characters, genetic investigations and germplasm development of sunflower with improved yield, oil quality, resistance to disease [Sunflower rust (Puccinia helianthi Schw.)], insect, Orobanche sp., and adverse conditions are under consideration. The research program is aiming to develop oilseed and confectionary type of sunflowers for both the first and second crop production seasons.

Sunflower germplasm has been developed from sources such as cultivars, populations created through breeding methods, or inter-specific crosses with wild germplasm and then tested for general and specific combining abilities, oil percentage, and resistance to prevalent disease and adverse conditions to construct improved varieties. For hybrid variety development, combining ability studies in oilseed and confectionary sunflower breeding program were undertaken with line $\times$ tester analysis.

More than 2000 lines, candidate varieties, and commercial varieties were evaluated in preliminary and yield trials in the first and second crop produc-

* Corresponding author: Phone: +902328461331/470; e-mail: a_s_tan@hotmail.com 
tion seasons. Variety performance tests and yield trials indicated that sunflower can be grown with satisfactory yield performance (approximately 500$550 \mathrm{~kg} \mathrm{da}^{-1}$ ) in both the first and second crop production seasons in the Aegean Region of Turkey.

Improvement of oilseed and confectionary types of sunflower parental germplasms (A, B and $R f$ lines) including hybrid and open pollinated varieties has been carried out. The oilseed type of the open-pollinated variety Ege-2001 was developed by the S 0:1 generation testing method (modified recurrent selection) and has been registered.

Effects of plant population, planting time, fertilizing, irrigation, and honeybee pollination on seed yield, oil percentage and other plant characteristics and silage quality of sunflower (Helianthus annuus L.) were determined. Sunflower rust (Puccinia helianthi Schw.) race identification was performed under field conditions.

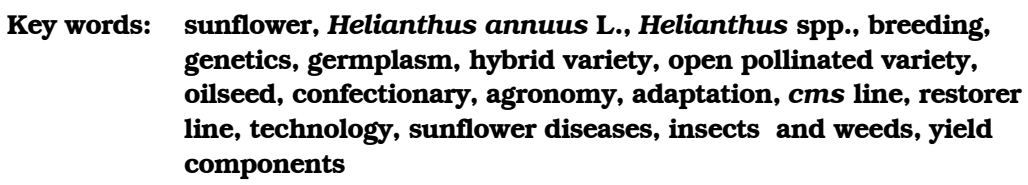

\section{INTRODUCTION}

Sunflower research activities have been conducted at the Aegean Agricultural Research Institute (AARI) since 1979. The Aegean Region has suitable ecological conditions for first and second crop sunflower production.

The mission of the Oilseed Research Project is to develop improved germplasm by conventional breeding techniques for the Aegean Region. New germplasm, breeding lines, and hybrid varieties have been developed. To improve oilseed and confectionary sunflower varieties with desired characters, genetic investigations and germplasm development of sunflower with improved yield, oil quality, resistance to diseases, insects, Orobanche cumana, and adverse conditions are under consideration. These studies are also incorporated with agronomic and other related researches.

\section{RESEARCH FINDINGS}

\section{Breeding and Genetics}

In the breeding programme a number of different approaches are utilized. Improved germplasm (populations and germplasm), new germplasm for hybrid development, and breeding lines of oilseed and confectionary type of sunflower [A (cms), B (maintainer) and $R f$ (restorer) lines] including hybrid and open pollinated varieties have been developed by conventional breeding techniques.

Combining ability studies in oilseed and confectionary sunflower breeding programs were undertaken with a set of line $\times$ tester including parents for the characters: seed yield, 1000-seed weight, days to flowering, days to physiological maturity, 
plant height, head diameter, stem diameter, oil content, fatty acid content (oleic, linoleic, palmitic, and stearic acids), protein content, seed length, seed width, and hull percentage. General (GCA) and specific combining abilities (SCA) of inbred lines and their hybrids were estimated in a line $\times$ tester analysis during the first and second crop production seasons in 1991. The variances due to GCA and SCA were highly significant for most of the characters in both environments. Based on GCA effects in the first and second crop production seasons, the inbreds ( $\mathrm{cms}$ and $R f$ lines) exhibited desirable GCA effects and were found to be good general combiners for most of the traits. Thus, they can be exploited by further breeding for developing superior genotypes and hybrids of sunflower (Tan, 1993; Tan, 2000a; Tan et al., 2003; Tan, 2004a; Tan, 2004b; Tan, 2004c; Tan, 2004d; Tan, 2005a; Tan, 2005b; Tan, 2009).

More than 200 oilseed- and confectionary-type cms and restorer $(R f)$ lines with higher GCA and SCA effects have been developed since 1983 (Tan, 2009).

Agronomic techniques have been applied for higher yield and to develop culturing techniques in sunflower.

On-farm research and adaptation studies (genotype $\times$ environment interaction) have been carried out to find out higher yielding varieties for different geographical regions and ecological conditions in both the first and second crop production seasons.

Evaluation and characterization of plant genetic resources to improve oilseed and confectionary types of sunflower germplasm and varieties are under consideration to maintain germplasm, regeneration and multiplication of plant genetic resources. These genetic studies allow us to develop new and desired sunflower germplasm (Tan et al., 2009).

Genetic and inheritance studies in sunflower to understand the genetic makeup of traits and genetic inheritance including disease resistance [Such as Puccinia helianthi Schw.; Plasmopara halstedii (Farl.) Berl de Toni.] and to improve drought tolerant varieties etc. in the breeding programs are under consideration.

Sunflower germplasm has been developed from sources such as cultivars, populations created through breeding methods, or interspecific crosses with wild germplasm and then tested for general and specific combining abilities, oil percentage, and resistance to prevalent disease and adverse conditions in order to construct improved varieties.

In this project (Tan, 2009), improvement of oilseed and confectionary types of sunflower germplasms including hybrid and open pollinated variety has been carried out. The oilseed type of the open pollinated variety Ege-2001 has been registered. More than 2000 lines, candidate varieties, and commercial varieties have been evaluated in preliminary and yield trials during the first and second crop production seasons since 1979. Variety performance tests and yield trials indicated that sunflower can be grown with satisfactory yield performance (500-550 kg da-1) 
in both the first and second crop production seasons in the Aegean Region of Turkey (Tan, 2006; Tan, 2007; Tan, 2009).

\section{Rust race identification}

Sunflower rust caused by Puccinia helianthi Schw. is considered one of the important foliar diseases of sunflower and is present wherever sunflower is grown in the world. The objective of this study was to identify the races of sunflower rust in the main sunflower production areas in Turkey. Experiments were conducted in six provinces (Aydin, Balikesir, Bursa, Denizli, Izmir, and Edirne) of Turkey in 1992. Race identification of $P$. helianthi was performed in field conditions. Eighteen differential genotypes were used to identify races of $P$. helianthi. Sunflower rust reactions of the differential genotypes were scored on a scale of 0 to 4 , where 0 to $2=$ resistant, 3 and $4=$ susceptible. Race 1 of $P$. helianthi, the causal agent of sunflower rust, was identified at Menemen - Izmir, Susurluk-Balikesir, KoçarliAydin, Çivril-Denizli. However, Races 1 and 3 of $P$. helianthi were found in Bursa and Edirne (Tan, 1993b; Tan, 1994a; Tan, 1994b).

\section{Effect of plant population on seed yield, oil percentage and other plant characteristics in sunflower}

In this study, the highest yield values, 2190 and $1920 \mathrm{~kg} \mathrm{ha}^{-1}$, were obtained with plant populations of 40,820 and 47,620 plants $^{-1}$, respectively. The most important observation was that the degree of lodging affected harvestable yield greatly. Lodging is associated with plant population size, stalk diameter, plant height, and wind speed. The number of lodged plants increased when plant population size was increased. The maximum wind speeds were 9.0 and $12.0 \mathrm{~m} \mathrm{~s}^{-1}$ in 1986 and 1987, respectively. The highest percentages of lodged plants were obtained at 95,240 plants ha ${ }^{-1}-69 \%$ and $19 \%$ in 1986 and 1987, respectively (Tan and Karacaoglu, 1991a).

\section{Effect of planting date on plant characteristics in sunflower}

Effects of planting date on seed yield, oil content, fatty acid composition and other plant characteristics in sunflower (Helianthus annuus L.) were determined on seven planting dates including both the first and second crop production times. The highest yields were obtained with early planting in the first and second crop planting times (beginning of April and July, respectively). In general, oil content was not affected by planting times. However, the fatty acid composition was changed significantly by planting dates depending upon temperature. Oleic acid composition was $45 \%$ in the early planting time and as planting time was delayed it decreased to $25 \%$ in the late planting time. The linoleic acid proportion increased from about $45 \%$ to $65 \%$ with the delaying plantings. The changes in fatty acid composition can be associated with temperature during seed development of the crop. The plant 
height, head diameter, and 1000-seed weight were also negatively affected as planting date was delayed (Tan, 1991).

\section{On-farm study of Orobanche cumana Wallr.}

Resistance and susceptibility of sunflower (Helianthus annuus L.) to Orobanche cumana Wallr. was determined under natural infection conditions. In this on-farm study, eight sunflower hybrids and the OP variety Vniimk-8931 were evaluated for their rates of resistance to O. cumana and for their agronomic performance. The hybrid variety TR 262 was consistently resistant, while the openpollinated variety Vniimk 8931 was found to be susceptible to Orobanche cumana Wallr. and had very low yield losses under natural infection. Since the hybrids TR 121, P 4014, Sunbred 262, TR 149, TR 270, Edirne 87, and IS 3312 had very low degrees of attack and infection rates, they could also be considered as resistant to Orobanche cumana Wallr. (Tan and Karacaoglu, 1991b).

\section{The effects of honeybee pollination on some economic characters of oil-type sunflower varieties}

This study was conducted to determine the effect of honeybee pollination on oiltype sunflower varieties (Super-25, AS-503, and ETAE-Y1) in 1997 and 1998 at AARI in Menemen - Izmir. The experimental design was a randomized block with split plot arrangement with three replications. The main plots were assigned to the pollination treatments and the sub-plots to sunflower varieties. Plot size was 16.17 $\mathrm{m}^{2}$ and the plant density was 40,816 plants $\mathrm{ha}^{-1}$. The plots of the treatments were 1) plots with honeybee pollination, 2) plots caged to exclude honeybee and other insect pollination, and 3) and open-pollinated plots.

The objectives of this research were to determine the effect of honeybee pollination on sunflower yield $\left(\mathrm{kg} \mathrm{da}^{-1}\right)$, 1000-seed weight $(\mathrm{g})$, plant height $(\mathrm{cm})$, head diameter $(\mathrm{cm})$, days to flowering, days to physiological maturity, oil percentage (\%), protein percentage (\%), hull percentage (\%), and seed sizes.

The results of statistical analysis indicated a significant difference among the treatments. The pollination efficiencies of Apis mellifera L. were investigated in insect-proof field cages of sunflowers and compared with honeybee pollinated and open-pollinated plots.

On average, the seed yields of honeybee pollinated plants were 444 and $413 \mathrm{~kg}$ $\mathrm{da}^{-1}$ in 1997 and 1998, respectively. All cultivars showed a significant increase in yield in the presence of bees. Seed yields of honeybee pollinated plants of three different sunflower varieties were, on average, $95 \%$ higher than those on plots caged to exclude bees in 1997, while in 1998 they were $124 \%$ higher. Yields were higher on plots pollinated by honeybees than on those caged to exclude bees and those with open-pollinated plants, but the difference varied between cultivars and between years. 
It is concluded that the use of honeybees for pollination also affected the seed size, 1000-seed weight, and oil and protein content (Tan, 2000b; Tan et. al., 2002).

\section{The effect of irrigation at various growth stages on some economic characters of first crop sunflower}

This research on the optimum and more economical irrigation treatment for oil-type sunflower varieties (Super-25 and Trakya-129) was conducted in 1996 and 1997 at AARI (Menemen - Izmir) in collaboration with the Village Affairs Research Institute. The treatments were: 1. non-irrigated (control), 2. one irrigation at the beginning of heading stage, 3 . one irrigation at the beginning of flowering (blooming) stage, 4 . one irrigation at the beginning of milk stage, 5. two irrigations at the beginning of heading and blooming stages, 6. two irrigations at the beginning of heading and milk stages, 7 . two irrigations at the beginning of blooming and milk stages, and 8. three irrigations at the beginning of heading, flowering and milk stages. The objectives of this research were: 1) to determine the number of irrigations during specific growth stages, and 2) measure the effect of irrigation on sunflower yield (kg $\left.\mathrm{da}^{-1}\right)$, 1000-seed weight $(\mathrm{g})$, plant height $(\mathrm{cm})$, head diameter $(\mathrm{cm})$, days to flowering, days to physiological maturity, oil percentage (\%), protein percentage (\%), hull percentage $(\%)$, seed length $(\mathrm{mm})$, seed width $(\mathrm{mm})$, and stem diameter $(\mathrm{cm})$. The results of statistical analysis showed a significant difference among the irrigation treatments. According to the results, the best yield was obtained with three irrigations $-427 \mathrm{~kg} \mathrm{da}^{-1}$ and $373 \mathrm{~kg} \mathrm{da}^{-1}$ in 1996 and 1997, respectively. By contrast, $347 \mathrm{~kg} \mathrm{da}^{-1}$ and $265 \mathrm{~kg} \mathrm{da}^{-1}$ were obtained from the control (non-irrigated) plots in 1996 and 1997, respectively.

The marginal analysis method was used for economic analysis. Generally, both of the registered varieties showed positive response to the applications in question. The eighth application (three irrigations at the beginning of heading, flowering, and milk stages) seems as if it is the most profitable treatment in terms of having the highest gross revenues. However, it does not have the highest ratio of marginal revenue to marginal costs; but the second application (irrigation at the development of head stage) provides the highest marginal revenues for both varieties with the minimum level of variable costs (3130000 TL). According to the results, three irrigations (at the beginning of heading, flowering, and milk stages) can be applied for high yield, but one irrigation at the development of the head stage is recommended because of satisfactory yield and the maximum marginal revenue (Tan, 1992; Tan et al., 2000).

\section{Silage quality of sunflowers}

Sunflower (Helianthus annuus L.) is known as a drought tolerant crop. Because of this property, it can be used as an alternative silage crop in both the first and second crop production seasons when irrigation is a limiting factor. This preliminary research was conducted to figure out the most suitable harvest stage of 
sunflowers for silage and evaluate silage quality of sunflowers harvested at different vegetation stages. In this study confectionary material ETAE-14 was planted by machine at a population of 40,816 plants ha $^{-1}$ in 1993 at Menemen. Plants were harvested at five different growth stages (R3, R5.1, R5.5-5.9, R6, R9), cut about 0.8 - $1.0 \mathrm{~cm}$ in length by the silage machine, and then stored in plastic barrels for silage. In the study, the material was evaluated for forage yield, flieg score, sensory quality, dry matter, crude protein, crude oil, crude fiber, N-free extract, ash, Ca, P, and $\mathrm{pH}$. The study's results showed that harvesting sunflower for silage during the R6 stage (complete flowering stage) (Schneiter, and Miller, 1981) is the most suitable stage for silage (Tan and Tumer, 1996).

\section{CONCLUSIONS}

In this research project, the desired oilseed and confectionary types of germplasm, populations, lines ( $\mathrm{cms}$ and $\mathrm{Rf}$ ), test hybrids, and varieties were developed in the breeding program and some additional agronomic studies were conducted to increase sunflower yield in the first and second crop production times in Turkey.

Research findings have been supported that instead of increasing the total acreage in sunflower production the second crop sunflower production can be used to increase sunflower production in Turkey. Therefore, the first and second crop sunflower productions should be considered in the Aegean Region in order to decrease the vegetable oil gap in Turkey.

\section{REFERENCES}

Anonymous. 2010. Sunflower production data. http://faostat.fao.org/.

Schneiter, A.A., and Miller, J.F., 1981. Description of sunflower growth stages. Crop Sci. 21: 901-903.

Tan, A.S. 1991. Effect of planting date on seed yield, oil content, fatty acid composition and other plant characteristics in sunflower (Helianthus annuus L.). In: Proc. Sunflower Research Workshop. Fargo, ND. 10-11 Jan., 1991. National Sunflower Assoc., Bismarck, ND. pp. 56-65.

Tan, A.S., 1992. Sicaklik ve suyun ayçiçeginde verim ve diger bazi karekteristikler üzerine etkileri. TYUAP Ege - Marmara Dilimi Tarla Bitkileri Toplantisi. 21 - 23 Mayis 1992. Ege Tar. Ara. Enst. Menemen, Izmir.

Tan, A.S., 1993. Ayçiçeginde (Helianthus annuus L.) melez varyete $\left(\mathrm{F}_{1}\right)$ islahinda kendilenmiş hatlarin çoklu dizi (Line $\times$ Tester) analiz yöntemine göre kombinasyon yeteneklerinin saptanmasi üzerine araştirmalar. Doktora tezi. E.Ü. Zir. Fak. Fen Bil. Ens. Tarla Bit. Ana Bil. Dali. Bornova - Izmir.

Tan, A.S., 1993. Identification of Rust (Puccinia helianthi Schw.) Races of Sunflower (Helianthus annuus L.). J. of Aegean Agricultural Res Inst. Anadolu 3(1): 63-72.

Tan, A.S., 1994. Occurrence, distribution, and identification of Rust (Puccinia helianthi Schw.) races of sunflower (Helianthus annuus L.) in Turkey. J. of Aegean Agricultural Res Inst. Anadolu 4(1): 26-37.

Tan, A.S., 1994. Ayçiçegi Pas (Puccinia helianthi Schw.) Irklarinin Ayçiçegi (Helianthus annuus L.) Üretiminin Yogun Olarak Yapildiigi Trakya, Güney Marmara ve Ege Bölgelerinde Dagilimi. Tarla Bitkileri Kongresi. 25-29 Nisan 1994. Cilt I. s.322 E.Ü.Z.F. Basimevi. Bornova. Izmir.

Tan, A.Ş., 2000a. Heterosis. Ege Tar. Ara. Enst. Yayin No. 96. Menemen, Izmir. 
Tan, A.S., 2000b. The importance of honeybee polination of sunflowers. In: Proc. TYUAP Workshop. Menemen-Izmir. 23-25 May 2000 Ministry of Agriculture. Aegean Agricultural Research Institute. Pub. No. 98, pp. 269.

Tan, A.S., 2004a. Heterosis. Bitki Islahi Egitimi (III). Tarim ve Köyişleri Bakanligi. Tarimsal Araştirmalar Genel müdürlügü. 13-17 Aralik 2004. Samsun.

Tan, A.S., 2004b. Kendine Uyuşmazlik . Bitki Islahi Egitimi (III). Tarim ve Köyişleri Bakanligi. Tarimsal Araştirmalar Genel müdürlügü. 13-17 Aralik 2004. Samsun.

Tan, A.S., 2004c. Kombinasyon Gücü. Bitki Islahi Egitimi (III). Tarim ve Köyişleri Bakanligi. Tarimsal Araştirmalar Genel müdürlügü. 13-17 Aralik 2004. Samsun.

Tan, A.S., 2004d. Line $\times$ tester analizi. Bitki Islahi Egitimi (III). Tarim ve Köyişleri Bakanligi. Tarimsal Araştirmalar Genel müdürlügü. 13-17 Aralik 2004. Samsun.

Tan, A.S., 2005a. Heterosis. Bitki Islahinda Istatistik Genetik Metotlar. Ege Tar. Ara. Enst. Menemen, Izmir. No.121: 33-71.

Tan, A.S., 2005b. Line $\times$ tester analizi. Bitki Islahinda Istatistik Genetik Metotlar. Ege Tar. Ara. Enst. Menemen, Izmir. No.121: 95-113.

Tan, A.S., 2006. Ayçiçegi Tarimi. Çiftçi Broşürü No: 136. Ege Tar. Ara. Enst. Menemen, Izmir.

Tan, A.S., 2007. Ayçiçegi Tarimi. p.41-83. TYUAP/TAYEK Ege - Marmara Dilimi Tarla Bitkileri Toplantisi. 2-4 Ekim 2007. Ege Tar. Ara. Enst. Menemen, Izmir.

Tan, A.S., 2009. Ege Bölgesi Ayçiçegi Araştirmalari Projesi. 2009 Yili Gelişme Raporu (Sunflower Researches for Aegean Region of Turkey. Annual Report of 2009). Ege Tarimsal Arastirma Enstitüsu) Aegean Agriculture Research Institute). Menemen- Izmir, Turkey.

Tan, A.S., Tan, A., Aykas, L., Elmas, S., Yildizdal, I. and Peksuslu, A., 2009. Endüstri Bitkileri Genetik Kaynaklari Projesi. 2009 Yili Gelişme Raporu. (Industrial Crops Resources Research Project. Annual Report, 2009). Ege Tarimsal Arastirma Enstitüsu) Aegean Agriculture Research Institute). Menemen- Izmir, Turkey.

Tan, A.S., and Karacaoglu, N.N., 1991a. Effect of plant population on seed yield, oil percentage and other plant characteristics in sunflower (Helianthus annuus L). In: Proc. Sunflower Research Workshop. Fargo, ND. 10-11 Jan., 1991. National Sunflower Assoc., Bismarck, ND, pp. 43-52.

Tan, A.S., and Karacaoglu, N.N., 1991b. Resistance and susceptibility of sunflower (Helianthus annuus L.) to Orobanche cumana Wallr. under natural infection. In: Proc. Sunflower Research Workshop. Fargo, ND. 10-11 Jan., 1991. National Sunflower Assoc., Bismarck, ND. pp. 17-24.

Tan, A.S., Tümer, S., 1996. Ayçiçeginin silajlik degerinin saptanmasi üzerine bir araştirma. Anadolu 6(1): 45-57.

Tan, A.S., Öztürk, A.I., Karaca, Ü., 2002. Tozlayici olarak Balarisi Kullaniminin Ayçiçeginde Verim ve Kaliteye Etkileri. J. Of Anadolu 12:1-26.

Tan, A.S., Emel, E., A.K. ve M. Kupal., 2003. Hibrit Ayçiçegi Islahi. Sonuç Projesi Raporu. Ege Tar. Ara. Enst. Menemen, Izmir.

Tan, A.S., Beyazgül, M., Avcieri, Z., Kayam, Y., Kaya, H.G., 2000. Ana ürün Ayçiçeginde Farkli Gelişme Devrelerinde Uygulanan sulamanin Verim ve Kaliteye Etkileri. Anadolu 10(2): 1-34. 